\title{
INDIVIDUAL AND CONTEXTUAL FACTORS IN DETERMINING ATTITUDES TOWARDS CRIME AND PUNISHMENT
}

\author{
Elena D'Agostino ${ }^{391}$ \\ Emiliano Sironi ${ }^{392}$ \\ Giuseppe Sobbrio ${ }^{393}$
}

https://doi.org/10.31410/itema.2018.1141

\begin{abstract}
The paper looks at the market for crime focusing on attitudes toward punishment and law obedience as expressed and collected by the fifth round of the European Social Survey in 2010. We find that highly educated people living in less corrupted countries show relatively more tolerant attitudes towards lawlessness and require less severe punishments for crimes. Compared to the previous literature, it confirms a modern view of fighting crime, based on education and civic sense rather than on fines and jail.
\end{abstract}

Keywords: attitudes, crime, punishment

\section{INTRODUCTION}

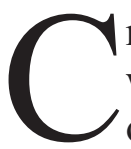

rime negatively affects economies as well as private and business life. Reducing crime works as business-promoting policy and for a reason it has always been considered as one of the most urgent tasks of any public policy agenda. However, how to intervene is still an open question, especially when the main goal is to prevent crime rather than implementing sanctions.

The economic approach to crime consists of viewing it simply as a human behavior motivated by rationality (Becker, 1968), where the crucial role is played by the demand of punishment and by the supply of crime (to be intended as the response of offenders to changes in enforcement). In this paper we examine the determinants of people attitudes toward punishment and law obedience to verify what sort of people asks for harsher punishment and stricter law obedience, and why.

On the side of the supply of crime, several attempts have been made in the literature to find possible explanations of why people break the law and to isolate the effect of specific features on crime: Muroi and Baumann (2009) find that the effect of wealth on crime in US is non-linear and turns out negative for rich countries and positive for poor countries; Buonanno et al. (2014) find an asymmetric response of crime to variations in unemployment, depending on economic conditions. Looking at more personal issues, a strong finding in criminology is that gender significantly and negatively affect crime in favor of women (Steffenmeier and Allan, 1996); a similar effect has been found also for religion (Baier and Wright, 2001). Similarly, there is strong evidence that education reduces both crime (Buonanno and Leonida, 2006; Freeman, 1996; Gould et al. 2002; Machin and Meghir, 2004; Viscusi, 1986) and the probability of incarceration (Lochner and Moretti, 2004).

\footnotetext{
${ }^{391}$ University of Messina, Piazza Pugliatti 198123 Messina, Italy

${ }^{392}$ Chatolic University of Milan, Italy

${ }^{393}$ University of Messina, Piazza Pugliatti 198123 Messina, Italy
} 
On the side of the demand for legality and punishment, public knowledge concerning crime is primarily derived from the media (Roberts and Doob, 1986; Surette, 1998) and empirical studies show a strong positive relationship between fear of crime and media consumption (Barille, 1984; Bryant et al., 1981; Hawkins and Pingree, 1980; Morgan, 1983; Weaver and Wakshlag, 1986; Williams et al., 1982). Evidence from Chicago also shows that poverty and economic recession are associated with higher tolerance of criminal behaviors independently of racial differences (Sampson and Bartusch, 1998).

Great attention has also been devoted in the literature on people beliefs and preferences in order to explain why severity of criminal codes and incarceration rates (Levitt, 2004) significantly vary around the world. Reasons have been traditionally found in both socio-economic factors and in psychological motivations. Di Tella and Dubra (2008) propose a theoretical model in which the demand for punishment is based on beliefs on the economic system that, in turn, produce a difference in meanness. If effort pays, such as in the "American dream" philosophy, being criminal is considered mean and deserves harsh punishment. In this way they explain why, example given, punishment (including death penalty) is harsher in US rather than in most European countries.

In the European culture it is rather true that asking for harsher punishment is usually associated to blind passion and insecurity, and refers to uncivilized, barbarian societies; whereas democracy and culture, together with higher levels of education and wealth, should work as an effective motivation to respect the law and contribute to determine milder attitudes toward punishment (Beccaria, 1764; Schmideberg, 1960) ${ }^{394}$.

Our approach does not directly focus on any of the two sides of the crime market, but tries to reconstruct both indirectly by looking at people attitudes towards punishment and law obedience as they emerge from the fifth round of the European Social Survey (from now on ESS). ESS is a two-year multi-country survey involving 25 European countries with the purpose of mapping attitudes, beliefs and behaviors of people in Europe. It consists of a questionnaire that can be classified into two parts: a core section and a rotating section. The former is designed to measure a range of topics of enduring interest, whereas the latter contains new topics of relevant interest at the time of the survey. A module in the rotating section of Round 5 in 2010 (not reproduced in Round 6) was Justice. We have selected three items from this module to capture people attitudes toward punishment (Item 1: "People who break the law should be given much harsher sentences than they are these days") and law obedience (Item 2: "All laws should be strictly obeyed" and Item 3: "Doing the right thing sometimes means breaking the law"). Precisely, attitudes toward punishment should capture the sense of (un)safeness inside the society and may work as a proxy of the demand for punishment. We find that high educated people living in less corrupted countries show a higher level of safeness or, at least, more tolerant attitudes. The result seems striking because these people are less likely to commit crimes and their attitudes cannot be interpreted selfishly as a way to be inflicted milder convictions. Compared to the previous literature, it rather confirms a modern view of fighting crime, based on education and civic sense rather than on fines and jail in line with the European tradition.

It makes even more interesting to look at the other side of the hypothetical market for crime to reconstruct the supply of crime, to be intended as a person's predisposition to become criminal. The difficulty is that nobody would answer sincerely to a direct question, such as "did you ever

\footnotetext{
${ }^{394}$ For a complete survey, see Polinsky and Shavell (2000).
} 
break the law?" or "did you ever commit crimes?" Accordingly our approach consists of looking at the demand for order and legality as expressed in the degree of agreement to items 2 and 3 in the ESS. Showing a strong agreement to item 2 and a strong disagreement to item 3 could be interpreted as a blind and total trust in the legal system that should not leave room to illegal behaviors. Vice versa, mild answers to both items seem to support a less intransigent approach to law and may hide the admission "yes, I may decide to break the law because if I believe it is the right thing to do".

We understand that the genuineness of our results crucially depends on whether it is methodologically correct to focus on attitudes, as expressed by the answers to a survey. As a matter of fact, this is not the first attempt to analyze and understand people attitudes towards punishment and legality. Using data from the world value survey, Torgler and Schneider (2007) investigated the determinants of attitudes towards paying more or less in taxes from a crosscountry perspective, considering the impact of both socio-demographic and cultural background. Further studies have focused on the relationship between education and crime, commonly arguing that education and the associated higher earnings negatively affect both crime (Buonanno and Leonida, 2006; Freeman, 1996; Gould et al. 2002; Machin and Meghir, 2004; Viscusi, 1986) and psychological attitudes towards crime (Arrow, 1997). More closely related to our research question, Groot and Van Den Brink (2010) found evidence of a relationship between high education levels and attitude towards serious crimes in the Netherlands. D'Agostino et al. (2013) confirmed these findings in a cross analysis involving most European countries. What is common to all these papers is that each focuses on a particular aspect (media, economic recession, education) to establish the potential effect on attitudes. Our paper goes further and puts together individual variables (involving personal features, such as gender, race, education, family), and contextual variables (referring to institutional and economic aspects, such as corruption, GDP, growth, interpersonal safety). To our knowledge, this is one of the first attempts to consider mixed variables, individual and contextual, in a systematic analysis of the determinants of attitudes towards legality and punishment. Our results suggest that both types of variables influence attitudes, but the effect of the individual variables dominates.

This result is not itself surprising, but a different matter is to interpret attitudes as prodromal to behaviors. The psychological literature supports this reconstruction as expressed by Ajzen (1991) and his theory of planned behavior ${ }^{395}$. It would mean that people who are less likely to commit crimes, according to the previous mentioned literature, should show strict attitudes toward law obedience and punishment. In fact our data tell a different story. Education and corruption, among all the other variables, seem rather to have an opposite effect on attitudes and on behaviors: highly educated people living in less corrupted countries show milder attitudes toward punishment and law obedience although they are less likely to commit crimes according to the previous literature. This raises important questions about the social dimension of crime as a complex phenomenon involving the individual's life within society. What we mean is that even if no causality effect has been found between attitudes and behaviors it does not necessarily mean that they are not related at all. Respecting the law is the first step for a peaceful and pleasant life. However, when the level of trust in public institutions is very high, that is primarily where perceived corruption is very low, the marginal positive effect on security

\footnotetext{
395 The theory of planned behaviour (TPB) says that an individual's decision to engage or not engage in a given behaviour is anticipated by the formation of positive intentions towards that behaviour. In Ajzen's (1991) view, intentions depend, among others, on personal attitudes towards a given behaviour. Applications of TPB can be found in Environmental Economics (see Koger and Du Nann Winter, 2010), Health Economics (see Liou and Bauer, 2007) and entrepreneurship (see Kautonen et al., 2013).
} 
of an increase in penalties and/or of strict law obedience is considered so low that conscious and highly educated people are reluctant to agree to such a policy. Showing relatively mild attitudes does not therefore hide admission of past or future criminal behaviors, but rather a personal consciousness to establish what is right and what is not right beyond (and not in contrast to) the law.

The paper is organized as follows. The next section presents the data and the model used in the analysis. The empirical results are then discussed and an interpretation offered which is consistent with the existing literature. Finally, conclusions are drawn.

\section{DATA AND METHODS}

This work uses cross-sectional data available from the European Social Survey (ESS). ESS is a two-year multi-country survey supported by the European Commission, the European Social Science Foundation and other financing institutions for each participant country (Belgium, Bulgaria, Cyprus, the Czech Republic, Denmark, Estonia, Finland, France, Germany, Greece, Hungary, Ireland, Israel, the Netherlands, Norway, Poland, Portugal, Russia, Slovakia, Slovenia, Spain, Sweden, Switzerland, the United Kingdom, the Ukraine). To give an idea of the size of the sample, 50,668 people were interviewed during the fifth round of the ESS in 2010 .

The interviews are conducted anonymously using questionnaires that include some core sections focusing on the socioeconomic characteristics of those in the sample; for this reason, the questionnaires have been reproduced unchanged every two years since the first edition of the survey (2002). Less frequently, the dataset also includes other sub-sections focusing on specific topics: one such sub-section in the fifth round referred to attitudes towards legality and to the level of trust in justice in European countries.

This study consists of an analysis on attitudes, viewed as ' $[\ldots]$ disposition[s] to react favorably or unfavorably to a class of objects' (SARNOFF, 1960, p. 279). As the aim is to analyze the determinants of attitudes toward punishments and law obedience, the following three questions were selected from the ESS Round 5 (original item numbers given in parentheses):

1. People who break the law should be given much harsher sentences than they are these days. (Item 1)

2. All laws should be strictly obeyed. (Item 2)

3. Doing the right thing sometimes means breaking the law. (Item 3)

The participants were asked to indicate the extent of their agreement or disagreement with each of these three statements according to a five-point Likert scale. The levels of responses for the items listed above are the dependent variable. We interpret answers to the first item as attitudes towards punishments and answers to the second and third items together as attitudes towards law obedience.

The distribution of responses in the selected sample is summarized in Table 1: 
Table 1. Frequencies of attitudes towards crime (ESS Round 5)

\begin{tabular}{|c|c|c|c|}
\hline & $\begin{array}{c}\text { People who break the } \\
\text { law should be given } \\
\text { much harsher sentences } \\
\text { than they are these days }\end{array}$ & $\begin{array}{c}\text { All laws should be } \\
\text { strictly obeyed }\end{array}$ & $\begin{array}{c}\text { Doing the right thing } \\
\text { sometimes means } \\
\text { breaking the law }\end{array}$ \\
\hline Strongly agree & $\begin{array}{c}11,752 \\
(23.86 \%)\end{array}$ & $\begin{array}{c}12,540 \\
(25.07 \%)\end{array}$ & $\begin{array}{c}3,276 \\
(6.86 \%)\end{array}$ \\
\hline Agree & $\begin{array}{c}22,365 \\
(45.41 \%)\end{array}$ & $\begin{array}{c}26,060 \\
(52.09 \%)\end{array}$ & $\begin{array}{c}20,175 \\
(42.26 \%)\end{array}$ \\
\hline Neither agree or & 10,332 & 7,777 & 12,507 \\
disagree & $(20.98 \%)$ & $(15.55 \%)$ & 9,678 \\
\hline Disagree & 4,241 & 3,283 & $(20.27 \%)$ \\
\hline Strongly disagree & $(8.61 \%)$ & $(6.56 \%)$ & 2,099 \\
& $(1.14 \%)$ & 368 & $(4.40 \%)$ \\
\hline
\end{tabular}

As can be seen, if the low levels of consensus for 'Strong disagreement' regarding the first two items are excluded, the distributions of the responses appear relatively balanced among the options presented. For the sake of simplicity of the empirical analysis, we have divided responses into two main categories, 'Agree' and 'Disagree': the former aggregates both the options 'Strongly agree' and 'Agree', whereas the latter collects the remaining alternatives ('Neither agree nor disagree', 'Disagree', 'Strongly disagree'). We have decided to include 'Neither agree nor disagree' in the 'Disagree' category because of the interpretation of attitudes we propose. Precisely, if we claim that attitudes toward punishment interpret a general feeling of unsafeness, showing indifference in respect to the correspondent item cannot be associated to a demand for harsher punishment. A similar argument can be replicated for attitudes toward law obedience (items 2 and 3). The new dichotomous variable used for the empirical analysis shows the following distribution:

Table 2. Frequencies of attitudes towards crime (recoded)

\begin{tabular}{|c|c|c|c|}
\hline & $\begin{array}{c}\text { People who break the } \\
\text { law should be given } \\
\text { much harsher sentences } \\
\text { than they are these days }\end{array}$ & $\begin{array}{c}\text { All laws should be } \\
\text { strictly obeyed }\end{array}$ & $\begin{array}{c}\text { Doing the right thing } \\
\text { sometimes means } \\
\text { breaking the law }\end{array}$ \\
\hline Agree & $\begin{array}{c}34,117 \\
(69.27 \%)\end{array}$ & $\begin{array}{c}38,600 \\
(77.16 \%)\end{array}$ & $\begin{array}{c}23,451 \\
(49.12 \%)\end{array}$ \\
\hline Disagree & $\begin{array}{c}15,133 \\
(30.73 \%)\end{array}$ & $\begin{array}{c}11,428 \\
(22,84 \%)\end{array}$ & $\begin{array}{c}24,284 \\
(50.88 \%)\end{array}$ \\
\hline
\end{tabular}

A multilevel logistic model is employed for two reasons: 1) the use of a dichotomous response variable; (2) the hierarchical organization of the data. With regard to the latter, the aim is to capture both individual and institutional aspects in determining attitudes towards legality. Accordingly, countries are at the first level of the hierarchical model and individuals assigned to a given country according to their residence are at the second level. Using a latent variable approach, the model is organized as follows:

where $y_{i j}^{*}$ is the propensity to agree with each of the statements presented in Table $3 ; x_{i j}^{T}$ is the vector containing the observed covariates at the individual level with the related coefficient $\beta$ 
$; z_{i}^{T}$ is the vector of observed covariates at the country level with the related coefficient $\gamma$. This means that every individual $j$ located in the same country $i$ presents identical values of $z_{i}^{T}$, but may present different values of $x_{i j}^{T}$. The error term is decomposed in the form:

$$
u_{i j}=\mu_{i}+\varepsilon_{i j}
$$

where the $\mu_{i}$ component is the country-level variable, whereas the $\varepsilon_{i j}$ component is the countryand individual-level variable.

We assume that, on the one hand, $\mu_{i}$ has a normal distribution with a mean of 0 and a variance of $\sigma_{\mu}^{2}$. This means that:

$$
\mu_{i} \sim N\left(0, \sigma_{\mu}^{2}\right)
$$

On the other hand, to identify the model, it is assumed that $u_{i j}$ has a logistic distribution with a mean of 0 and a variance of $\sigma_{\varepsilon}^{2}=\pi^{2} / 3$.

Given the purpose of the paper, the role of the intra-class correlation $\rho$ is of great importance in the model. This is defined as follows:

$$
\rho=\operatorname{corr}\left[y_{i j}^{*}, y_{i j^{\prime}}^{*} \mid x_{i j}, x_{i j^{\prime}}, z_{i}\right]=\frac{\sigma_{\mu}^{2}}{\sigma_{\mu}^{2}+\pi^{2} / 3}
$$

The $\rho$ coefficient explains the within-country correlation in predicting the probability of an agreement with the items due to unobservable factors.

As already mentioned, the individual variables included in the ESS Round 5 are combined with some contextual variables, taken from different sources (see below). Starting with the first category of variables, as included in the ESS and following Groot and Van Den Brink (2010) and D'Agostino et al. (2013), the following explanatory variables are used:

a. Age: it is a continuous variable expressed in completed years.

b. Education: it comprises two separate indicators for the highest level of education, one for the respondent and the other for his/her father. Due to the strong heterogeneity of the education systems among European countries, individuals are compared according to the International Standard Classification of Education (ISCED), created by UNESCO as a worldwide system of classification of education courses and related degrees. Precisely, ISCED level 0-1 refers to children aged 3-11 years and internationally corresponds to pre-primary or primary education; ISCED level 2 corresponds to lower secondary education; ISCED 3-4 means that the respondent completed upper secondary education; ISCED levels 5, 6 and 7 are associated with university education at undergraduate, graduate and post-graduate levels, respectively.

c. Gender: female is the reference category. 
d. Employment: it is ranked in five categories (unemployed, employed, students, pensioners and other ${ }^{396}$ ).

e. Children: it is a dummy variable that takes the value 1 if the respondent (and/or his/her partner) has a child and 0 otherwise.

f. Born in the country of residence: it is a dummy variable that takes the value 1 if the respondent was born in the same country as that of residence at the time of the interview and 0 otherwise.

g. Urbanization level (first residence): it is a dummy variable that takes the value 1 if the respondent lives in a large town and 0 if he/she lives in a small town or a village;

h. Religiosity: it is a dummy variable derived using an ordinal scale from 1 (the individual reports not being a religious person) to 10 (the individual reports being very religious) based on self-assessment. The dummy takes the value 1 if the level declared is at least equal to 6 and 0 otherwise.

The vector of the contextual variables, that is variables measured at the state level, includes the following:

a. GDP per capita: it is the gross domestic product per capita, i.e. the market value of all officially recognized final goods and services produced per capita in the observed country in 2010, measured in thousands of dollars. The source is the World Bank.

b. GDP growth: it is the growth rate of GDP between 2009 and 2010. The source is the official report of the World Bank.

c. Corruption perceptions index: it is a variable derived from the Corruption Perceptions Index (CPI). According to Transparency International, the CPI is an index measuring the perception of corruption in the public sector and in politics in many countries around the world. It assigns each country a rating ranging from 0 (maximum corruption) to 10 (absence of corruption). The methodology is revised each year to make the index as reliable as possible. The survey was carried out by Universities or other study centers on behalf of Transparency International for the year 2010. ${ }^{397}$

d. Interpersonal safety and trust: it is a variable obtained from the Institute of Social Studies site, measuring (for the year 2010) personal security and trust by using data on general social trust from a wide variety of surveys, indicators of trustworthiness such as reported levels of crime victimization, survey responses on feelings of safety and security in one's neighborhood, data on the incidence of homicide and risk reports on the likelihood of physical attack, extortion, or robbery.

e. Legal origin: it is a control variable that classifies the countries as French, English, German, Nordic or Socialist according to the origin of their legal system. ${ }^{398}$ As shown by La Porta et al. (2008), legal origin may have an impact on behaviors (and perhaps on attitudes).

To sum, Table 3 provides an overview of the variables used in the hierarchical model.

\footnotetext{
${ }^{396}$ The category 'Other' is a residual category including people involved in community or military service, doing housework, or looking after children or other persons.

${ }^{397}$ There is also in the literature a similar index offered by the World Bank, sampled and used in this study for internal analysis as a proof of robustness. The results are perfectly in line with those of the Transparency International index, selected to diversify the sources of data.

${ }^{398}$ According to La Porta et al. (2008), countries in which the legal system originates from the civil law tradition are classified as either French or German depending on whether they derive from the Napoleon code or from Kelsen's tradition respectively; those in which the legal system originates from the common law tradition are classified as English, Nordic and Socialist and comprise countries in Northern and Eastern Europe respectively.
} 
Table 3. List of explanatory variables in the model

\begin{tabular}{|c|c|}
\hline$x_{i j}^{T}$ & $z_{i}^{T}$ \\
\hline Sources: European Social Survey, Round 3, 2010 & World Bank, Transparency International \\
\hline Age (in years) & $\begin{array}{l}\text { Gross domestic product (GDP) per } \\
\text { capita } \\
\text { (thousands of dollars) }\end{array}$ \\
\hline Education $(I S C E D<2, I S C E D=2-3, I S C E D=4, I S C E D \geq 5)$ & $\begin{array}{l}\text { Gross domestic product growth (GGDP) } \\
(\%)\end{array}$ \\
\hline $\begin{array}{l}\text { Father's education (ISCED }<2, I S C E D=2-3 \text {, ISCED }=4 \text {, } \\
I S C E D \geq 5)\end{array}$ & $\begin{array}{l}\text { Legal origin (French, German, } \\
\text { Scandinavian, English, Nordic, } \\
\text { Socialist) }\end{array}$ \\
\hline Gender (male, female) & $\begin{array}{l}\text { Corruption perceptions index }(\mathrm{CPI}) \text {, } \\
\text { Transparency }\end{array}$ \\
\hline $\begin{array}{l}\text { Employment status (unemployed, employed, student, retired, } \\
\text { other) }\end{array}$ & $\begin{array}{l}\text { Interpersonal Safety and Trust Index, } \\
\text { Institute of Social Studies }\end{array}$ \\
\hline Number of children $(0 ; \geq 1)$ & \\
\hline Born in the country of residence (no, yes) & \\
\hline Urbanization level of first residence (small town, large city) & \\
\hline Religiosity $(1-5,6-10)$ & \\
\hline
\end{tabular}

Because of the high correlation between the Corruption perceptions index and Interpersonal safety and trust (Pearson's correlation coefficient $=0.67$ ), it was decided to replace these variables with a unique factor, extracted using principal components analysis. The factor, named Control of corruption and interpersonal safety, summarizes approximately $83 \%$ of the variability in the two indices and is positively correlated with both the indicators; in other words, the higher the level of the factor, the lower the level of corruption and the higher the level of interpersonal safety and trust in the country.

\section{RESULTS}

As said in the Introduction, studying attitudes is important, on the side of the demand of justice, in order to comprehend to what extent citizens feel safe and, on the side of the supply of crime, in order to anticipate and possibly prevent future (illegal) behaviors. The three items of the ESS we have analyzed cover both these aspects: the first item refers to the demand of justice, whereas the last two interpret together the tendency of respecting the law and, a contrario, the tendency of committing crimes.

The results of the empirical analysis are summarized in Table 4. Since we have used both individual and contextual variables, we have decided to isolate the effect of the former category and, for this purpose, we propose two columns of coefficients for each item: the first column refers to regressions in which only individual-level variables have been used (and thus the contextual variables take the value 0 ); the second column includes both the individual and the contextual variables. 
Table 4. Empirical results of regression analysis

\begin{tabular}{|c|c|c|c|c|c|c|}
\hline Context variables & \multicolumn{2}{|c|}{$\begin{array}{l}\text { People who break the } \\
\text { law should be given } \\
\text { much harsher sentences } \\
\text { than they are these days }\end{array}$} & \multicolumn{2}{|c|}{$\begin{array}{l}\text { All laws should be } \\
\text { strictly obeyed }\end{array}$} & \multicolumn{2}{|c|}{$\begin{array}{l}\text { Doing the right thing } \\
\text { sometimes means } \\
\text { breaking the law }\end{array}$} \\
\hline $\begin{array}{l}\text { Control of corruption and } \\
\text { interpersonal safety }\end{array}$ & & $-0.328 * * *$ & & $-0.472 * * *$ & & $0.396 * * *$ \\
\hline GDP per capita & & -0.012 & & -0.018 & & $-0.028^{*}$ \\
\hline GGDP & & -0.014 & & -0.008 & & 0.052 \\
\hline \multicolumn{7}{|l|}{ Legal origin } \\
\hline Socialist & & 0 & & 0 & & 0 \\
\hline French & & 0.464 & & $0.464 *$ & & -0.116 \\
\hline German & & $0.919 * * *$ & & $0.792 * * *$ & & -0.388 \\
\hline English & & $0.948 * * *$ & & $0.907 * * *$ & & -0.439 \\
\hline Nordic & & $0.733 * *$ & & $0.957 * * *$ & & -0.557 \\
\hline Age & 0.001 & 0.001 & $0.010 * * *$ & $0.010 * * *$ & $-0.005 * * *$ & $-0.005^{* * *}$ \\
\hline \multicolumn{7}{|l|}{ Education of the respondent } \\
\hline$I S C E D<2$ & 0 & 0 & 0 & 0 & 0 & \\
\hline ISCED 2 & $-0.080 *$ & $-0.080 *$ & 0.015 & 0.017 & 0.058 & 0.057 \\
\hline ISCED 3-4 & $-0.091 * *$ & $-0.092 * *$ & -0.056 & -0.053 & $0.104 * * *$ & $0.104 * * *$ \\
\hline$I S C E D \geq 5$ & $-0.480 * * *$ & $-0.479 * * *$ & $-0.137 * * *$ & $-0.133^{* * *}$ & $0.193 * * *$ & $0.192 * * *$ \\
\hline \multicolumn{7}{|l|}{ Father's education } \\
\hline$I S C E D<2$ & 0 & 0 & 0 & 0 & 0 & 0 \\
\hline ISCED 2 & $-0.080 * *$ & $-0.082 * *$ & -0.008 & -0.007 & -0.009 & -0.008 \\
\hline ISCED 3-4 & $-0.080 * *$ & $-0.082 * * *$ & $0.069 * *$ & $0.069^{* *}$ & -0.008 & -0.008 \\
\hline$I S C E D \geq 5$ & $-0.269^{* * *}$ & $-0.269 * * *$ & -0.054 & -0.052 & $0.064 * *$ & $0.063 *$ \\
\hline \multicolumn{7}{|l|}{ Gender } \\
\hline Female & 0 & 0 & 0 & 0 & 0 & 0 \\
\hline Male & $-0.180 * * *$ & $-0.180 * * *$ & $-0.126^{* * *}$ & $-0.125^{* * *}$ & $0.172 * * *$ & $0.171 * * *$ \\
\hline \multicolumn{7}{|l|}{ Employment status } \\
\hline Unemployed & 0 & 0 & 0 & 0 & 0 & 0 \\
\hline Employed & $0.124 * * *$ & $0.124 * * *$ & $0.169 * * *$ & $0.170 * * *$ & $-0.120 * * *$ & $-0.121 * * *$ \\
\hline Student & $-0.101 * *$ & $-0.099 *$ & $0.164 * * *$ & $0.167 * * *$ & $-0.095^{*}$ & $-0.096^{* *}$ \\
\hline Other & $0.142 * * *$ & $0.142 * * *$ & $0.314 * * *$ & $0.316^{* * *}$ & $-0.080^{*}$ & $-0.080 *$ \\
\hline Retired & $0.178^{* * *}$ & $0.177 * * *$ & $0.316^{* * *}$ & $0.315^{* * *}$ & $-0.194 * * *$ & $-0.194^{* * *}$ \\
\hline \multicolumn{7}{|l|}{ Number of children } \\
\hline 0 & 0 & 0 & 0 & 0 & 0 & 0 \\
\hline$\geq 1$ & $0.098 * * *$ & $0.098 * * *$ & 0.027 & 0.028 & 0.015 & 0.015 \\
\hline \multicolumn{7}{|l|}{$\begin{array}{l}\text { Born in the country of } \\
\text { residence }\end{array}$} \\
\hline Yes & 0 & 0 & 0 & 0 & 0 & 0 \\
\hline No & -0.043 & -0.043 & $-0.224 * * *$ & $-0.226 * * *$ & $0.057 *$ & $0.057 *$ \\
\hline \multicolumn{7}{|l|}{$\begin{array}{l}\text { Urbanization level (first } \\
\text { residence) }\end{array}$} \\
\hline Small town & 0 & 0 & 0 & 0 & 0 & 0 \\
\hline Big city & $-0.092 * * *$ & $-0.093 * * *$ & $-0.075 * * *$ & $-0.076^{* * *}$ & $0.055^{* * *}$ & $0.056^{* * *}$ \\
\hline \multicolumn{7}{|l|}{ Religiosity } \\
\hline Not religious & 0 & 0 & 0 & 0 & 0 & 0 \\
\hline Religious & 0.020 & 0.020 & $0.280 * * *$ & $0.279 * * *$ & $-0.142 * * *$ & $-0.142 * * *$ \\
\hline
\end{tabular}




\begin{tabular}{|l|r|r|r|r|r|r|}
\hline$\hat{\rho}$ & $0.064 * * *$ & $0.017 * * *$ & $0.070 * * *$ & $0.029 * * *$ & $0.061 * * *$ & $0.022 * * *$ \\
\hline Observations & 49,017 & 49,017 & 49,789 & 49,789 & 47,510 & 47,510 \\
\hline
\end{tabular}

We find that $\hat{\rho}$ is very low with respect to all the items even without including the contextual variables (first columns), showing that most of the variability is due to the individual variables. This is not surprising as attitudes towards punishment and law obedience tend to depend by definition on the individual's sensitivity towards social norms. Nevertheless, we note that $\hat{\rho}$ decreases in the regressions in which the contextual variables are included (second columns), demonstrating that they contribute to explaining variability at the country level. A first conclusion is therefore that attitudes towards punishment and law obedience depend primarily on personal characteristics.

We now interpret our results in order to answer the following questions: what does determine people demand for harsher punishment? Are attitudes toward law obedience informative about a person's tendency of breaking laws?

To answer these questions, we first look at the three items together. What immediately emerges is that some variables are significant in respect to all the three items: Education, Gender, Employment, Urbanization level of first residence, Corruption and Interpersonal safety. These 'core variables' affect the first two items ('People who break the law should serve more severe punishments than today' and 'Laws should be strictly observed') in the same way as shown by the coefficient signs, whereas the opposite results arise with respect to the third item ('Doing the right thing sometimes means breaking the law'). It is not surprising that people who do not believe that tougher punishments should be applied are also those who do not believe that laws should be strictly observed, but rather agree that breaking the law is sometimes the right thing to do. What is surprising is the sort of people expressing such tolerant opinions concerning crime and punishment. Indeed, what emerges from the regressions is that tolerance is supported for all the core variables except Employment. In other words, it seems that highly-educated males, especially students, living in large urban areas and in less corrupt countries show milder and more tolerant attitudes towards punishment and law obedience in that they tend to agree that breaking laws is sometimes the right thing to do. Precisely, the result for Employment, combined with that for Education, suggests that low-skilled people looking for a job are less tolerant than low-skilled employed people, who are in turn less tolerant than highly-skilled employed people. By the way, it cannot be meaningless that Education is more significant and plays a greater role in respect to all the items only at the highest ISCED level $(\geq 5)$. An identical result can be observed looking at the effect of Father's education on attitudes: although there is no ISCED level turning out significant for all the three items, it is clear that this variable plays a role, especially in influencing attitudes toward punishment.

What follows is that, on the one hand, people trust each other to the extent that they accept that breaking the law might be the right thing to do in some circumstances; on the other hand, these results seem to support the claim that education and culture serve as better motivation than harsher punishments. Some of these results simply confirm the existing literature, such as the role of Education with respect to items 2 and 3 (D'Agostino et al., 2013; Groot and Van Den Brink, 2010), which is also extended to item 1.

This interpretation is corroborated by the effect of the remaining core variables, Urbanization level and Corruption and Interpersonal safety. About the former, rebus sic stantibus, it seems that living in big towns makes people more tolerant despite the evidence in favor of small towns where the crime rate tends to be lower. Again a so surprising effect can be justified in the light 
of the different cultural and educational level characterizing small and big towns in favor of the latter.

About Corruption and Interpersonal safety, keeping in mind that higher values are associated with lower levels of corruption and higher safety perception in the country analyzed, a negative coefficient means that people living in less corrupt countries show more tolerant attitudes towards crime and punishment. In light of previous considerations, we can conclude that if institutions are associated with social order and stability and therefore low corruption and high safety, people living in countries in which laws are commonly observed tend to be more tolerant because breaking laws is considered an exceptional event that does not affect the quality of their daily lives. Accordingly, they also realize that tougher punishments may not be an effective policy. This reaction is emphasized, among all, by Education.

Conversely, those accustomed to living in degraded environments, in which laws are commonly unobserved, tend to be strict and intransigent because they probably believe that more law obedience and tougher punishments are the easiest way to get order and security.

Even if not included into the core variables, also Legal origin seems to play a significant role in respect to both attitudes toward punishment and law obedience limited to item 2: not surprisingly all categories (German, English, Nordic and to a slightly lower extent, French) are associated with less indulgent positions than the Socialist category. However, Legal origin does not play a significant role in determining whether people may find it right to break the law (item 3), so it cannot be said that it helps explain attitudes as well as behaviors. In contrast, GDP per capita is significant only for the third item, whereas no significant effect can be attributed to GDP growth. Finding support for this result is difficult as there is a general consensus in the literature that high wages have a strong and consistent deterrent effect on crime (see CalvòArmengo et al., 2007; Myers, 1983). However, high wages usually correspond to high-skilled (and therefore highly-educated) employees, so that the result has to be interpreted in a similar way of what already said for Education and Employment status.

Moving far from the core variables, we find that other explanatory variables are significant to explain only one of the two attitudes analyzed and therefore require a differentiated analysis.

On the side of the demand for punishment Children turn out significant, whereas attitudes toward law obedience are significantly influenced by Age, Religiosity, Born in the country and GDP. Among these variables, special attention should be devoted to Children and Religiosity. On the one hand, it is not surprising that both variables make people more intransigent: the significant and positive effect of Children on attitudes toward punishment can be easily explained by the visceral and blind desire to protect children (see Welch, 2011), and the significant and positive (negative) effect of Religiosity on answers to the second and third items finds support in the existing literature that religion can play a deterrent effect on crime (Baier and Wright, 2001) given that most crimes correspond to sins in most religions practiced in Europe. On the other hand, it is certainly striking that Children and Religiosity do not significantly affect respectively attitudes toward law obedience and punishment. Focusing on the former variable, parents are expected to teach their children what is allowed and what is forbidden; looking at the latter variable, most religions (including those mainly practiced in Europe) claim serious punishment for sinners after death. On a deeper thought, this result can be explained as follows: even assuming that most parents teach their children to respect the law, it does not mean that being parents change a person's view of whether laws should be always strictly obeyed or not. Similarly, being religious has not to be associated to a demand of harsher 
punishments, but should rather make people more prone to forgive, as shown by Sandys and McGarrell's (1997) with respect to attitudes towards capital punishment. Moreover, and more importantly, the two results together seem to support the claim that people responses are based on their perceived sense of safeness, so that attitudes may be informative in this sense, especially those toward punishment where respondents have no reason to lie. We can therefore conclude that the demand for harsher punishment follows unsafeness, as procured by high corruption levels and low education levels.

The analysis becomes rather complicated turning to attitudes toward law obedience (items 2 and 3) as indirect expression of the tendency of respondents to respect/break the law. Before drawing some conclusive remarks, we have to say that also Age and Born in the country of residence show a significant effect of making people more intransigent. On the one hand, the strain theory (Agnew, 2009) helps explain the result about Age stating that adolescents are more exposed than adults to the experience of strain that leads to crime. However, the coefficient we find is so low $(0,010$ and -0.005 respectively for the second and the third item) that it cannot support the thesis that young people are less prone to obey the law. On the other hand, the effect of immigration is controversial. Bianchi et al (2012) and Martens (1997) find evidence respectively for Italy and Sweden that the size of the immigrant population is positively correlated only with the incidence of specific types of crime, such as robbery or violent crime. Butcher and Morrison Piehl (1998) find that cities with high crime rates tend to have large numbers of immigrants, but youth born abroad are statistically significantly less likely than native-born youth to be criminally active.

To sum, comparing our results with the existing literature on the supply of crime (see the Introduction), the effects of Education and Corruption on attitudes and behaviors clearly go to opposite directions, making people attitudes more tolerant and behaviors more legally oriented. On the contrary, Age, Religiosity, Gender (Female) and, to some extent, Employment status, Born in the Country of Residence and Urbanization level show effects on attitudes more aligned to those on behaviors. We can therefore conclude that attitudes serve the purpose of explaining behaviors only partially because civic sense and culture make the difference.

\section{CONCLUSION}

Using data from ESS Round 5, this study has focused on the determinants of attitudes towards punishment and law obedience, testing the effect of individual variables previously used in the literature (D'Agostino et al., 2013; Groot and Van Den Brink, 2010), together with certain contextual variables which, to the best of our knowledge, have never previously been used for this purpose. The results show that individual factors explain most of the variability at the country level, but that contextual variables also make a contribution.

We see that the demand for harsher punishment is mainly due to unsafeness: highly educated people living in non-corrupted countries feel more secure or, at least, believe that punishments have not to be harsher. A similar effect emerges turning to attitudes toward law obedience. In particular, the negative effect of Control of corruption and interpersonal safety proves that the institutional context plays a significant, though unexpected, role. If, on the one hand, good institutions promote social order and legality and work as a constraint against breaking the law, on the other hand, they allow more tolerant attitudes towards crime and punishment. 


\section{REFERENCES}

AGNEW R. (2009) Juvenile Delinquency: Causes and Control. Oxford University Press, Oxford;

AJZEN I. (1991) The theory of planned behavior, Organizational Behavioral and Human Decision Processes 50, 179-211;

ARROW K. (1997) The benefit of education and the formation of preferences, in BEHRMAN, J. and STACEY, N. (Eds) The Social Benefits of Education, pp. 11-15. University of Michigan Press, Ann Arbor, MI;

BAIER C. J. and WRIGHT B. R. E. (2001) If you love me, keep my commandments: A metaanalysis of the effect of religion on crime, Journal of Research in Crime and Delinquency 38(1), 3-21;

BARILLE L. (1984) Television and attitudes about crime: Do heavy views distort criminality and support retributive justice? In SURETTE, R. (Ed) Justice and the Media: Issues and Research, Charles C. Thomas, Springfield, Illinois;

BECCARIA C. (1764) Dei delitti e delle pene. Marco Coltellini, Livorno;

BECKER G. (1968) Crime and punishment: An economic approach, Journal of Political Economy 76, 169-217;

BIANCHI M., BUONANNO P. and PINOTTI P. (2012) Do immigrants cause crime? Journal of the European Economic Association 10(6), 1318-47;

BRYANT J., CARVETH R. A. and BROWN D. (1981) Television viewing and anxiety: An experimental examination, Journal of Communication 31, 106-19;

BUONANNO P., DRAGO F., and GALBIATI R. (2014) Response of crime to unemployment. An international comparison, Journal of Contemporary Criminal Justice 30(1), 29-40.

BUONANNO P. and LEONIDA L. (2006) Education and crime: Evidence from Italian regions, Applied Economics Letters 13, 709-13;

BUTCHER K. F. and MORRISON PIEHL A. (1998) Cross-city evidence on the relationship between immigration and crime, Journal of Policy Analysis and Management 17(3), 45793;

CALVÓ-ARMENGO A., VERDIER T. and ZENOU, Y. (2007) Strong and weak ties in employment and crime, Journal of Public Economics 91(2), 203-33;

D'AGOSTINO E., SIRONI E. and SOBBRIO G. (2013) The role of education in determining the attitudes towards crime in Europe, Applied Economics Letters 20, 724-27;

DI TELLA R. and DUBRA J. (2008) Crime and punishment in the "American Dream", Journal of Public Economics (92), 1564-1584.

FREEMAN R. B. (1996) Why do so many young American men commit crimes and what might we do about it? Journal of Economic Perspectives 10, 25-42;

GOULD E., MUSTARD D. and WEINBERG B. (2002) Crime rates and local labor market opportunities in the United States: 1979-1997, The Review of Economics and Statistics $84,45-61$;

GROOT W. and VAN DEN BRINK H. M. (2010) The effects of education on crime, Applied Economics 42, 279-89;

HAWKINS R. and PINGREE, S. (1980) Some progress in the cultivation effect, Communication Research 7, 193-226;

KAUTONEN T., TOMIKOSKI E., and VAN GELDEREN M. (2013) Predicting entrepreneurial behavior: A test of the theory of planned behavior, Applied Economics 45(6), 697-707;

KOGER, S. and DU NANN WINTER D. (2010) The Psychology of Environmental Problems. Psychology Press, New York;

LA PORTA R., LOPEZ-DE-SILANES F. and SHLEIFER A. (2008) The economic 
consequences of legal origins, Journal of Economic Literature 46(2), 285-332;

LEDERMAN D., LOAYZA N. V. and SOARES R. R. (2005) Accountability and corruption: Political institutions matter, Economics \& Politics 17(1), 1-35;

LEVITT S.D. (2004). Understanding Why Crime Fell in the 1990's: Four Factors That Explain the Decline and Six That Do Not, Journal of Economic Perspectives 18, 163-90.

LIOU D. and BAUER K. D. (2007) Exploratory investigation of obesity risk and prevention in Chinese Americano, Journal of Nutritional Education Behavior 39(3), 134-41;

LOCHNER L. and Moretti E. (2004). The Effect of Education on Crime: Evidence from Prison Inmates, Arrests, and Self-Reports. American Economic Review, 94(1): 155-189.

MACHIN S. and MEGHIR C. (2004) Crime and economic incentives, The Journal of Human Resources, 39, 958-79;

MARTENS P. L. (1997) Immigrants, crime, and criminal justice in Sweden, Crime and Justice 21, 183-255;

MORGAN M. (1983) Symbolic victimization and real-world fear, Human Communication Research 9(2), 146-57;

MUROI C. and BAUMANN R. (2009) The non linear effect of wealth on crime, Economics Department Working Papers. Paper 36.

MYERS Jr. S. L. (1983) Estimating the economic model of crime: Employment versus punishment effects, Quarterly Journal of Economics 98(1), 157-66;

POLINSKY M. and SHAVELL S. (2000) The economic theory of public enforcement of law, Journal of Economic Literature 38, 45-76;

ROBERTS J. and DOOB A. (1986) Public estimates of recidivism rates: Consequences of a criminal stereotype, Canadian Journal of Criminology 28, 229-41;

SAMPSON R. J. and BARTUSCH D. J. (1998) Legal cynicism and (subcultural?) tolerance of deviance: The neighborhood context of racial differences, Law and Society Review 32(4), 777-804;

SANDYS M. and MCGARRELL E. F. (1997) Beyond the Bible belt: The influence (or lack thereof) of religion on attitudes toward the death penalty, Journal of Crime and Justice 20(1), 179-190;

SARNOFF I. (1960) Psychoanalytic theory and social attitudes, Public Opinion Quarterly 24, 251-79;

SCHMIDEBERG, M. (1960) The offender's attitude toward punishment, Journal of Criminal law and Criminology 51, 328-334;

SURETTE R. (1998) Media, Crime, and Criminal Justice: Images and Realities, 2nd Edition. Wadsworth Publishing, New York;

TORGLER B. and SCHNEIDER F. (2007) What shapes attitudes toward paying taxes? Evidence from multicultural European countries, Social Science Quarterly 88(2), 443-70;

VISCUSI W. K. (1986) Market incentives for criminal behavior, in Freeman R. B. and Holzer H. J. (Eds) The Black Youth Employment Crisis, pp. 201-51. University of Chicago Press, Chicago, IL;

WEAVER J. and WAKSHLAG J. (1986) Perceived vulnerability to crime, criminal experience and television viewing, Journal of Broadcasting and Electronic Media 30, 141-58;

WELCH K. (2011) Parental status and punitiveness: Moderating effects of gender and concern about crime, Crime and Delinquency 57(6), 878-906;

WILLIAMS T., ZABRACK M. and JOY L. (1982) The portrayal of aggression on North American television, Journal of Applied Social Psychology 12, 360-80. 